Giovanni Forcina, Monica Guerrini, Melinda Zeder and Filippo Barbanera

\title{
The Black Francolin: Assessing the Origins of a Prized Courtly Bird in an Interdisciplinary Manner
}

Some animals are somehow paradoxical: well impressed in the collective imaginary of the recent past, perhaps even legendary, they might be nonetheless soon removed from our memory. Among these, the black francolin (Francolinus francolinus, Galliformes; see Figure 1), a pheasant-like bird known as Attagen or Attagas in the Classical Age, is an exemplary case. The dramatist Aristophanes, the natural philosopher Pliny the Elder, the lyric poet Horace, the epigrammatist Martial: these are only some of the eminent ancient Greek and Latin authors mentioning this bird in their works. ${ }^{1}$ Currently found from Cyprus and the Middle East eastwards to the Indian subcontinent with six morphological subspecies inhabiting a variety of open ground habitats, the black francolin was also found in Italy and Spain until the nineteenth century. ${ }^{2}$ However, the nativeness of the species to such areas was seriously doubted and the origin of these putatively imported westernmost populations shrouded in secrecy. ${ }^{3}$

The present study brings together historical evidence and results from DNA analyses to reconstruct the origins and uses of the black francolin in the Mediterranean area from the medieval period to the nineteenth century. As we will see, these birds largely owed their importation and survival from the Late Middle Ages to the nineteenth century to the needs of princes for exclusive and tasty game animals. Accordingly, deprived of fostering and special protection, their presence in Western Europe ended together with the age of the courts of the Ancien Régime.

1 See the editions by Thompson D’Arcy (1895): 37-38; Borghini et al. (1983).

2 Madge McGowan (2002): 193-198.

3 See for example, Martorelli (1906): 20. 


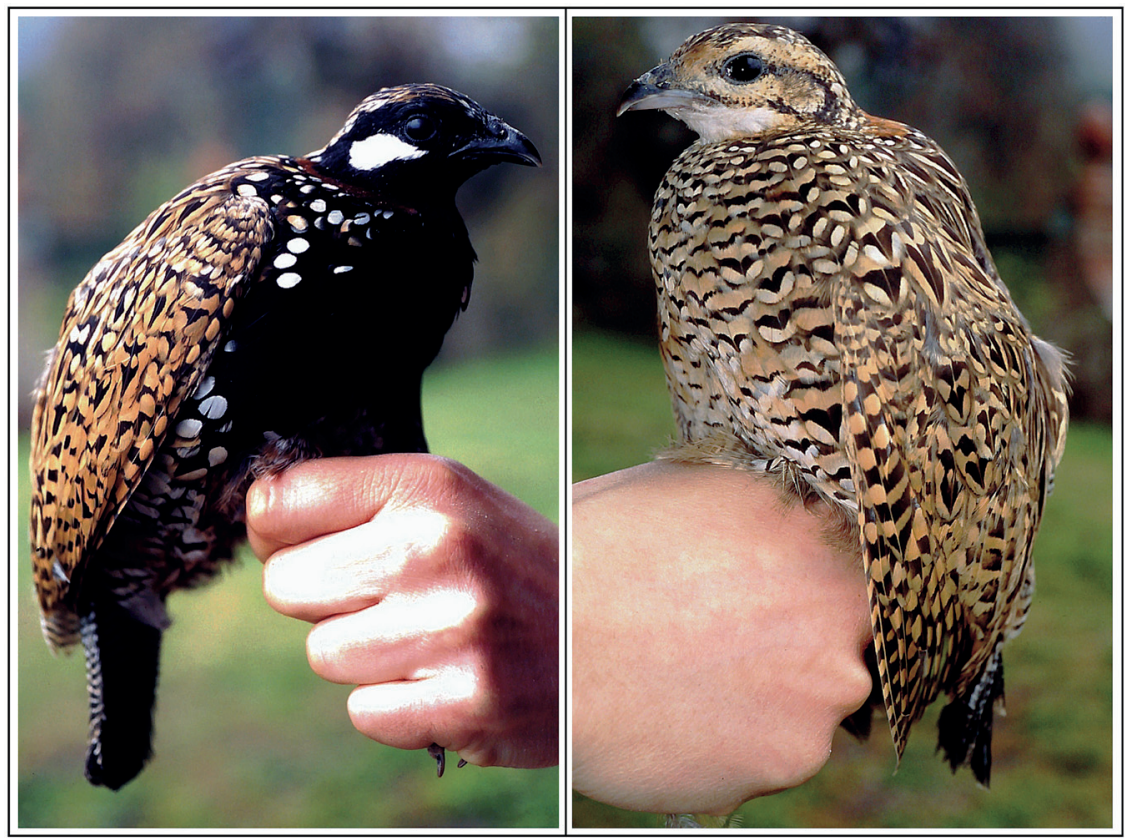

Fig. 1: A couple of black francolins (Francolinus francolinus asiae), male (left) and female (right)

\section{Food for Gourmets, Game for Nobles: The Black Francolin in Historical Sources}

Long celebrated as a true delicacy, the meat of this bird was also thought to possess remarkable medical (for this reason it was sometimes referred to as Predice Asculapica) and even aphrodisiac properties. ${ }^{4}$ Concerning the supposed curative powers of the black francolin, it is worth reporting that in the sixteenth century, the Spanish viceroy in Sicily, Lope de Vega, described these birds as "useful on several occasions for human body health". ${ }^{5}$ Later, seventeenth-century Italian naturalist Giovanni Pietro Olina praised their meat as not only incredibly flavoured, but also as a portentous remedy against kidney problems. ${ }^{6}$ Interestingly, such benefits were acknowledged also in the Islamic culture, its higher digesti-

4 See Cosman (1983): 1-33; Adamson (2004): 37.

5 "utili in molte occorrenze per la salute dei corpi umani." Pragmatic sanction of 10 March 1550 promulgated by Viceroy and Captain General of Sicily Juan de Vega y Enríquez de Acuña. 6 James (1753). 
bility making this food specifically recommended in place of chicken for pilgrims travelling to Mecca. ${ }^{7}$

For all of these reasons, the black francolin was held in high regard by the aristocracy in Medieval and Renaissance Europe and was often demanded as a courtly gamebird. ${ }^{8}$ Similar to exotic relatives from faraway places such as the peacock (Pavo cristatus), the common pheasant (Phasianus colchicus), and the Guinea fowl (Numida meleagris), ${ }^{9}$ it was also kept as an ornamental bird in model farms and parks, either free ranging or captive in menageries. This was the case for the Medici villa in Poggio a Caiano (Florence) in grand ducal Tuscany in the fifteenth century, the aviary of Cardinal Scipione Borghese in papal Rome in the sixteenth and seventeenth centuries, and, later, La Favorita hunting estate in Bourbon-Sicily in the nineteenth century. ${ }^{10}$ In Spain, the bird was reared in El Pardo, Aranjuez, and El Escorial, two royal estates near Madrid, and was particularly appreciated by King Philip II of Spain in the sixteenth century.

The strong interest of the mighty and powerful is also documented by the severe bans restricting the hunting of this bird to ruling elites enacted in Spain, Sicily and the Grand Duchy of Tuscany from the thirteenth century onwards. Penalties for the offenders ranged from exorbitant fines to life imprisonment and corporal punishment such as public whipping and even the cutting of hands. ${ }^{11}$ For example, the ban proclaimed in March 1550 by the Spanish viceroy in Sicily, Juan de Vega, reported a "200-ounce fine for each offender to be paid to the Treasury, or an appropriate prison sentence for low-born people". ${ }^{12}$ Unlike the common pheasant that was mostly hunted with dogs, ${ }^{13}$ the black francolin was traditionally hunted by falconry, as reported in the famous treaty De arte venandi cum avibus by Holy Roman Emperor Frederick II and in coeval documents of the Islamic culture. ${ }^{14}$

The charismatic bird is mentioned in a number of letters exchanged by Italian and Spanish rulers in the Late Middle Ages where the species is regarded as a

\footnotetext{
7 Luqa (1992): 89.

8 Ortalli (1985): 1389-1443.

9 Lamblard (2003).

10 Oriani (2014).

11 Baldacci (1964): 16-18.

12 “[...] pena onze 200 in pro dell'erario in ogni trasgressore, o di galea ad arbitrio del Governo qualora il reo fosse persona di basso rango.” Pragmatic sanction of 10 March 1550 promulgated by Viceroy and Captain General of Sicily Juan de Vega y Enríquez de Acuña.

13 See Anderson (1975).

14 See Trombetti Budriesi (2000); Viré (1969): 113-139.
} 
symbol of wealth and prestige. ${ }^{15}$ One such example is a letter dated 26 May 1368 and sent by the Catalan king Peter IV of Aragon from Sicily to the governor of Mallorca, informing him about the shipment of pheasants and francolins to be reared in the local Esporles estate. Another letter, written by the poet Michele Verino before May 1487, reports that Lorenzo the Magnificent himself had solicited and obtained the shipment of some black francolins from Sicily to his model farm in Poggio a Caiano. ${ }^{16}$ Remarkably, there are documents proving that the Medici imported a number of francolins from Sicily to their dominions. ${ }^{17}$

The black francolin is also portrayed as a valuable game species in a number of still life paintings realized in the same countries during the seventeenth century. In most of these representations, male birds with their brightly coloured and strikingly patterned plumage are preferred to the pale and cryptic females. Some examples are the oil paintings on canvas Still Life with Cardoon, Francolin, Grapes, and Irises by Felipe Ramirez and Still Life with Birds and Hare (see Figure 2) by Tomás Yepes as well as Still Life with Game Birds (Lombard School, private collection, Milan, end of the seventeenth century). The best example, however, is probably The Hunters' Gathering by the Flemish painter Justus Sustermans, where a male francolin is portrayed as a trophy at a highborn hunters' rendez-vous (see Figure 3).

When the strict protection ended, however, the black francolin rapidly disappeared from the Western Mediterranean due to uncontrolled harvest and land reclamation. ${ }^{18}$ It is worth mentioning the belated attempts by the Bourbons to save the species from extinction in Sicily with the offer of cash prizes for people protecting nests and broods. Poor flyers and mediocre runners, these birds were easily spotted because of the male calls heard across long distances; they were caught with nets, snares, and even bare hands. ${ }^{19}$ As noted by the Bolognese nobleman, agronomist, and gastronome, Vincenzo Tanara, ${ }^{20}$ the increasing use of firearms heavily contributed to the carnage of this game bird, whose short-distance linear flights made the job quite easy for shooters. Finally, egg depredations gave the final blow ${ }^{21}$ and the bird was officially declared extinct in Sicily in $1869 .^{22}$

15 Masseti (2009).

16 Masseti (2002): 211-213.

17 Encyclopédie Méthodique (1784): 50.

18 Andreotti et al. (2001): 136.

19 Olina (1622): 33.

20 Tanara (1886).

21 Carvana (1889): 516-520.

22 Doderlain (1874): 9-72. 


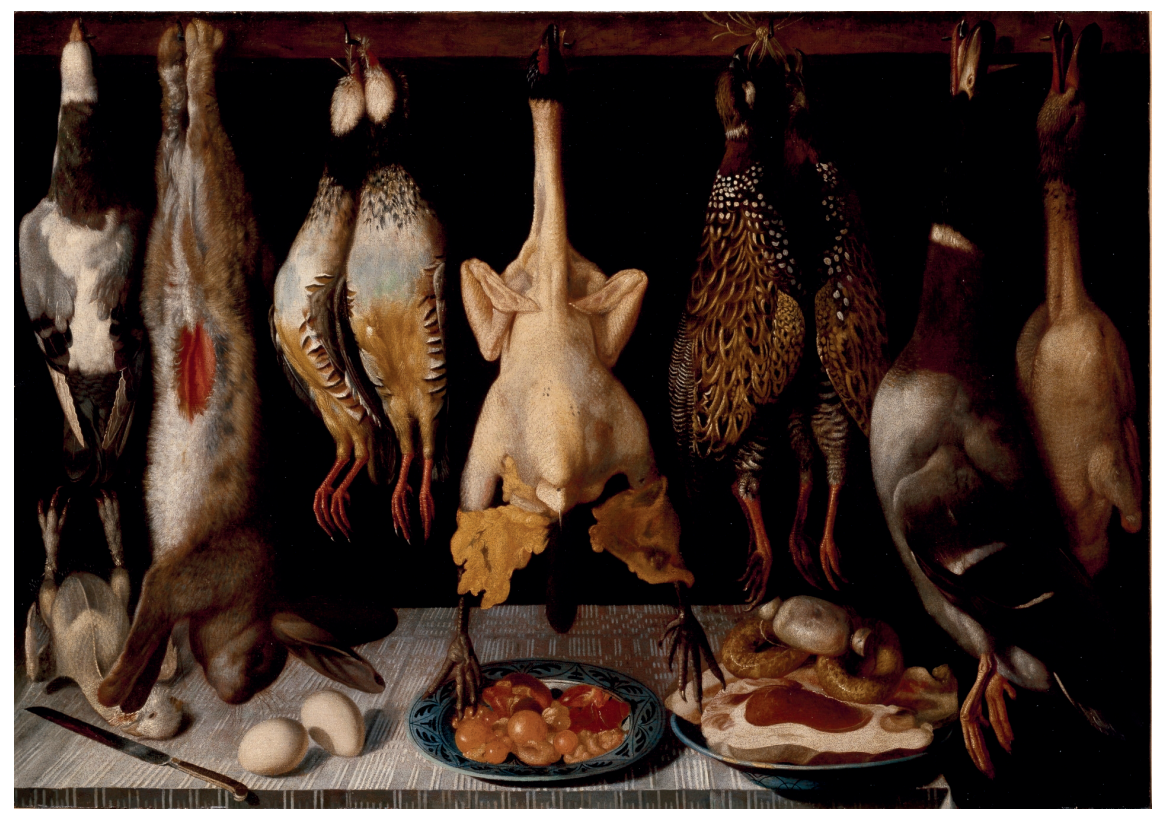

Fig. 2: Tomás Yepes, Still life with birds and hare, 1643 (Madrid, Museo del Prado). A pair of black francolin males (second from right) is portrayed along with mallards, red-legged partridges, a hare and a wood pigeon.

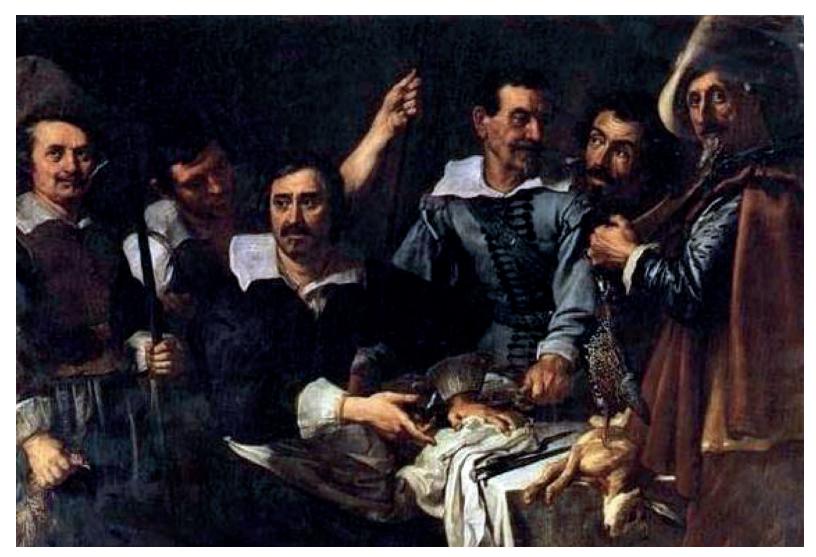

Fig. 3: Justus Sustermans, The Hunters' Gathering, 17th century (Florence, Palatine Gallery) 


\section{The Origins of the Black Francolin: The Results of a DNA Analysis}

Relying on a thorough historical documentation and an extensive DNA analysis of modern and archival specimens (mitochondrial DNA Control Region gene; $\mathrm{n}=281$ ), we aimed at unveiling the enigmatic origin of the black francolin in the Western Mediterranean and, at the same time, rescuing the memory of this prized bird from oblivion. The sample of modern birds included 205 specimens collected between 2007 and 2013. In addition, we also analyzed 76 samples from archival specimens housed in 15 museums in the United States and Europe, including 17 individuals from regions where the black francolin is now extinct. ${ }^{23}$

As far as the specific use of archival specimens is concerned, the majority of tissues used were toe pads of stuffed birds (see Figure 4). There is a double advantage in using this part of the animal: first, it has not generally been treated with chemicals (for example, formalin/formaldehyde), thereby inhibiting DNA amplifications; second, this operation does not leave visible traces on the exterior of the specimen. Not only did the use of such specimens enable us to investigate the historical populations from the Western Mediterranean (namely Tuscany, Sicily, and Spain), it also ensured an extensive and comprehensive sampling across the species range, which mostly stretches across remote and socio-politically unstable countries in Asia. Importantly, detailed information on collection sites and dates was a fundamental prerequisite, along with the overall state of preservation at the time of assessing the value of the archival specimens, thus selecting those to be included in the sample size. It was by scanning this information that the only two archival species of black francolin from Tuscany and Spain, both dating back to the first decades of the nineteenth century (and, as such, being the most ancient specimens still available), were identified in the natural history museums of Florence and Geneva respectively.

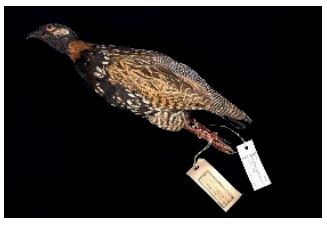

Fig. 4: Black francolin archival specimen, Spain, c. 1838 (Geneva, Muséum d'histoire naturelle)

The genetic results obtained were startling, pointing to the occurrence of two non-native geographically distinct genetic stocks in the Western Mediterra- 
nean. ${ }^{23}$ On the one hand, the estimated but not yet proven importation from Cyprus during the Crusades (specifically attributed to the Templars ${ }^{24}$ ) was confirmed on a molecular basis. On the other hand, strong evidence for importations from southern Asia through long-distance trade routes emerged. This overall scenario points to the black francolin, a bird of eastern origin, as one of the valued ornamental game birds that became part of the Western world's collective imaginary. ${ }^{25}$ Moreover, chronicles of European pilgrims and merchant travellers like Marco Polo exploring Asia report game birds like the chukar partridge (Alectoris chukar) as being used as fresh-food supply along the Silk Road. ${ }^{26}$ Particularly noteworthy is Florentine explorer Leonardo Frescobaldi's mention of the black francolin during his journey across the Holy Land around 1385, once again, celebrating its meat. ${ }^{27}$

Our findings also shed light on the likely role Portuguese merchants played in satisfying the elite's demand for exotic species at European courts during the Renaissance. ${ }^{28}$ The importance of Portuguese trading posts in western India and the trade monopoly they held in the Indian Ocean suggest a maritime route for the importation of black francolin Indian stocks to Europe. This possibility is further supported by molecular data, which show no evidence of Indian lineages in mainland Asia between India and the Mediterranean Basin. Definitive evidence for such trade might be found in repositories of archival documents about the history of Iberian countries in the East, such as the General Archive of the Indies in Seville. Another possibly pertinent bibliographic reference to the eastern origin of the black francolin may be found in a comment made by the Aragonese naturalist and Carthusian clergyman Diego de Funes y Mendoza in his translation of Aristotle's Historia Animālium in the seventeenth century, in which he describes the francolin as an "Asian bird introduced to France and Spain". ${ }^{29}$

While the Indian stock would have reached the Mediterranean through Lisbon and possibly Seville emporia, the Cypriot stock would have followed a more linear trajectory. First imported to Sicily, this stock seems to have been spread to southern Italy and Spain by the Catalan-Aragonese, as strongly suggested by the clear-cut overlap between their dominions and the historical distribution of

23 For more details, see Forcina et al. (2015).

24 Amari (1937): 1082-1084.

25 See for example Nair Thankappan (1974) for the peacock, and Ghigi (1958) for the common pheasant.

26 Barbanera et al. (2007).

27 Gargiolli (1862).

28 Ringmar (2006); Jordan Gschwend (2009).

29 Maluquer, Travé (1961). 
the black francolin in the Western Mediterranean. ${ }^{30}$ This is particularly true for Spain, where francolins were mainly found in Catalonia, Aragon, Valencia, the Balearics, as well as in the Roussillon province in France; but records from the dominions of Castilla are quite limited. There is also an etymological clue concerning the provenance of this stock. The term "francolin" is likely to derive from the Late Latin Gallina Franca referring to the fact that it had been imported by French (Frank) crusaders. ${ }^{31}$ The French Royal House of Lusignan ruled in Cyprus during the High and Late Middle Ages, making it quite possible that the French were responsible for the first shipments of francolins to Sicily and other destinations in the Central and Western Mediterranean.

\section{Conclusion}

Summing up the results of this work, we can say that the surprising results of our molecular DNA analyses find a plausible explanation in literary and iconographic records. Reference to these sources has allowed us to better evaluate molecular data pointing to the exotic origin of this species in Europe and provides important insight into both the mechanics and the larger geopolitical framework for the trade in this charismatic game species. The investigation of the bird specimens residing in museum collections played a major role in this work. And while no misidentification of taxidermied specimens of black francolins was discovered in this study, this work points to the potential value of molecular biotechnologies in enhancing the value of such archival resources. ${ }^{32}$ By pursuing an interdisciplinary approach, we were able to document the profound impact of geopolitics and trade relationships from the Late Middle Ages onwards in shaping Western Mediterranean biodiversity. On the other hand, it became evident how fruitful the exchange with zoologists could be in giving further value to humanists' daily work. The main lesson of this story is the paramount importance of integrating complementary information from different areas of expertise when addressing the process of biological globalization and the history of human-animal relationships. Also, this study evidences how, similar to other prized game birds such as the common pheasant, the presence of the black francolin in Western Europe was entirely attributable to the ongoing demand and protection by

30 Muntaner et al. (1983): 297-298.

31 Jiménez (2013).

32 For example, Barbanera et al. (2016). 
princely courts, yet in this case their persistence ceased definitively with the fall of the Ancien Régime.

\section{References}

Adamson, Melissa Weiss. Food in Medieval Times. Westport, CT: Greenwood Publishing Group, 2004.

Anderson, Liselotte. Fasan. Reallexikon zur Deutschen Kunstgeschichte, vol. 7, Munich: Beck, 1975, 429-436 (available online: www.rdklabor.de/wiki/Fasan, accessed 13 November 2017).

Amari, Gabriele. Avifauna siciliana scomparsa: il francolino. Diana 32, 1937, 1082-1084.

Andreotti, Alessandro, Nicola Baccetti, Antonio Perfetti, Marco Besa, Pietro Genovesi, and Vittorio Guberti. Mammiferi e uccelli esotici in Italia: analisi del fenomeno, impatto sulla biodiversità e linee guida gestionali. Quaderni di Conservazione della Natura, 2, 2011.

Tanara, Vincenzo, (s. d. XVII sec.) - La caccia degli uccelli. Manoscritto pubblicato a cura di Bacchi della Lega, Alberto, 1886. Romagnoli-Dall'Acqua, Bologna.

Baldacci, Ugo. Il Francolino, Sua Reintroduzione in Europa. Nistri-Lischi Editori, Pisa, 1964. Barbanera, Filippo, Beatrice Moretti, Monica Guerrini, Omar F. Al-Sheikhly, and Giovanni Forcina. Investigation of ancient DNA to enhance natural history museum collections: misidentification of smooth-coated otter (Lutrogale perspicillata) specimens across multiple museums. Belgian Journal of Zoology 146, 2016, 101-112.

Barbanera, Filippo, Monica Guerrini, Pantelis Hadjigerou, Panicos Panayides, Christos Sokos, Peter Wilkinson, Aleem A. Khan, Bakht Y. Khan, Fabio Cappelli, and Fernando Dini. Genetic insight into Mediterranean chukar (Alectoris chukar, Galliformes) populations inferred from mitochondrial DNA and RAPD markers. Genetica 131, 2007, 287-298.

Borghini, Alberto, Elena Giannarelli, Arnaldo Marcone, and Giuliano Ranucci. Gaio Plinio Secondo. Storia Naturale, II. Antropologia e Zoologia, Libri 7-11. Einaudi, Torino, 1983.

Carvana, G. Francolino. In Primo resoconto dei risultati della inchiesta ornitologica in Italia. Avifauna italica, elenco sistematico delle specie di uccelli stazionarie o di passaggio in Italia, parte I. Giglioli, Hillyer Enrico, 516-520. Le Monnier, Florence, 1889.

Cosman, Madeleine Pelner. A feast for Aesculapius: Historical diets for asthma and sexual pleasure. Annual Review of Nutrition 3, 1983.

Doderlein, Pietro. Avifauna del modenese e della Sicilia. Fascicolo sesto. Giornale di Scienze naturali ed economiche 10, 1874, 329-381.

Encyclopédie Méthodique. Histoire naturelle. Oiseaux. Tome II. Libraire Panckouke, Paris, 1784.

Forcina, Giovanni, Monica Guerrini, Hein van Grouw, Brij K. Gupta, Panicos Panayides, Pantelis Hadjigerou, Omar F. Al-Sheikhly, Muhammad N. Awan, Aleem A. Khan, Melinda A. Zeder, and Filippo Barbanera. Impacts of biological globalization in the Mediterranean: Unveiling the deep history of human mediated gamebird dispersal. Proceedings of the National Academy of Sciences of the United States of America 112, 2015, 3296-3301.

Gargiolli, Carlo. Lionardo di Niccolò Frescobaldi, Georgio Gucci, and Simone Sigoli. Viaggi in Terra Santa, di Lionardo Frescobaldi e d'altri del secolo XIV. Edizioni, Barbera, G., Florence, 1862, pp. 450. 
Ghigi, Alessandro. Fagiani, Pernici e altri Galliformi da caccia e da voliera. Edagricole, Bologna, 1958.

James, Robert. Dizionario universale di medicina. Tomo terzo. Giambatista Pasquali, Venice, 1753, pp. 683.

Jiménez, Juan. El curioso caso del francolin: extinguido tras 600 años de presencia en España. Quercus 330, 2013, 16-23.

Jordan Gschwend, Annemarie. A procura portuguesa por animais exoticos. Cortejo Triunfal com Girafas. Hallett, J. (ed.), 32-42. Fundacao Ricardo do Espirito Santo Silva, Lisbon, 2009.

Lamblard, Jean-Marie. L'Oiseau Nègre. L'Aventure des Pintades Dionysiaques. Editions Imago, Paris, 2003, pp. 184.

Luqa, Qusta ibn. Qusta ibn Luqa's Medical Regimen for the Pilgrims to Mecca. Edited with Translation \& Commentary, Bos, G., ed. Leiden, Brill, E. J., 1992, pp. 189.

Madge, Steve, Phil McGowan. Pheasants, Partridges and Grouse. Christopher Helm, London, 2002, pp. 488.

Maluquer, Joaquim i Sostres, Alfonso Federico Travé. Presencia y extincion del Francolin en la Peninsula Iberica e Islas Baleares. Ardeola 7 (1961): 129-156.

Martorelli, Giacinto. Gli uccelli d'Italia. Terza edizione riveduta ed aggiornata da Edgardo Moltoni e Carlo Vandoni. Rizzoli, Milano, 1960, pp. 860.

Masseti, Marco. Uomini e (non Solo) Topi. Gli Animali Domestici e la Fauna Antropocora. Florence: Firenze University Press, 2002, pp. 337.

Masseti, Marco. In the gardens of Norman Palermo, Sicily (twelfth century AD). Anthropozoologica 44, 2009, 7-34.

Muntaner, Jordi, Xavier Ferrer, and Albert Martínez-Vilalta. Atlas dels Ocells Nidificants de Catalunya i Andorra. Ketres, Barcelona, 1983, pp. 322.

Nair Thankappan, Parameswaran. The peacock cult in Asia. Asian Folklore Studies 33, 1974, 93-170.

Olina, Giovanni Pietro. Ucceliera, ovvero discorso della natura e proprietà di diversi uccelli e in particolare quelli che cantano, con il modo di prenderli, conoscerli, allevarli e mantenerli. Fei, A., Roma, 1622, pp. 216.

Oriani, Aldo. Dati storici sulla presenza circummediterranea del francolino nero Francolinus francolinus francolinus (Linnaeus, 1766). Rivista Italiana di Ornitologia - Research in Ornithology, 84, 2014, 11-22.

Ortalli, Gherardo. Gli animali nella vita quotidiana dell'alto medioevo: Termini di un rapporto. Atti del Convegno L'Uomo di Fronte al Mondo Animale Nell'Alto Medioevo, Spoleto 1983, ed Fondazione CISAM, Arti Grafiche Panetto \& Petrelli, Spoleto, 1985, 1389-1443.

Ringmar, Erik. Audience for a giraffe: European expansionism and the quest for the exotic. Journal of World History 17, 2006, 375-397.

Thompson D'Arcy, Wentworth A Glossary of Greek Birds. Oxford: Clarendon, 1895, pp. 240.

Trombetti Budriesi, Anna Laura. De arte venandi cum avibus di Federico II di Svevia. Edizione e traduzione italiana del ms. lat. 717 della Biblioteca Universitaria di Bologna collazionato con il ms. Pal. lat. 1071 della Biblioteca Apostolica Vaticana. Laterza, Bari, 2000.

Viré, François. Le traité de l'art de Volerie (Kitāb Al-Bayzara). Arabica 12, 1965, 113-139. 


\section{Image references}

Fig. 1: A couple of black francolins (Francolinus francolinus asiae), photo by Filippo Barbanera, 2008

Fig. 2: Tomás Yepes, Still life with birds and hare, 1643, Madrid, Museo del Prado

Fig. 3: Justus Sustermans, The Hunters' Gathering, 17th century, Florence, Palatine Gallery

Fig. 4: Black francolin archival specimen MHNG_701.083, Spain, c. 1838, Geneva, Muséum d'histoire naturelle, photo by P. Wagneur 
